ACTA UNIVERSITATIS LODZIENSIS

FOLIA LITTERARIA POLONICA 5(43) 2017

http://dx.doi.org/10.18778/1505-9057.43.01

Wojciech Adamczyk ${ }^{*}$

\title{
Muckraker websites (American and European examples)
}

Technology has changed mass communication. That is a banal statement, yet it perfectly indicates one of the factors that has determined the functioning of the mass media in over four centuries. Apart from political and economic conditions, it was the transformation which occurred in terms of how one acquires, processes, collects, distributes, and exchanges information that has mostly altered the landscape of the mass communication market as well as the mode in which editorial boards work. New technology requires both the media and journalists to adjust to the new conditions. That is visible in the work of investigative reporters who, just like the entire press community, adapted first the radio, later cable television, and eventually a whole host of new technologies of information transmission to the requirements of their job. The perfect example of that is the I-Team of American muckrakers': Donald L. Barlett and James B. Steele, who can boast a long cooperation and many awards. In 1973, at The Philadelphia Inquirer, the duo conducted a seven-month-long investigation using computers to analyse the data of over 1,000 individual criminal cases. They used the collected material to develop a series of articles about the local justice system, which, their findings revealed, did not operate in line with the principle of "blind justice" 2 . It is probable that

* Ph.D. hab., Wojciech.Adamczyk@amu.edu.pl; Department of Journalism, Faculty of Political Science and Journalism, Adam Mickiewicz University in Poznań.

${ }^{1}$ The term muckraker was derived from muckraking, literally translated as "scouring the dirt" (or "rummaging in the dirt"). It was first used during a public appearance in 1906 and its authorship has been assigned to Theodore Roosevelt. One of the meanings of muckraking is defined by the Webster dictionary as: to strive to reveal, to reveal or accuse of corruption, actual or alleged, politicians and corporations. The term was used to define the first American investigative journalists who revealed behind-the-scene activities of public figures who violated the law. The notion, regardless of the passage of time, is also currently used as a synonym for investigative reporters (vide: W. Adamczyk, "Amerykańskie archetypy dziennikarstwa śledczego", Wydawnictwo Naukowe Wydziału Nauk Politycznych i Dziennikarstwa Uniwersytetu Adama Mickiewicza, Poznan 2008, p. 11; W.L. Rivers, C. Mathews, "Etyka środków przekazu”, transl. by J. Zakrzewski, E. Krasnodębska, Ars Polonia, Warsaw 1995, p. 120).

2 J.L. Aucoin, "Investigative Journalism”, in: “American Journalism: History, Principles, Practices", W.D. Sloan, L.M. Parcell (eds.), McFarland, Jefferson, NC 2002, p. 209; J.L. Aucoin, "The Evolution of American Investigative Journalism", University of Missouri Press, Columbia, 
neither of the reporters expected at that time that they would become the progenitors of new methods for using computers, and, in the future, also information and communication technologies for the purposes of investigative journalism.

In contemporary times, the use of computers in editorial work in, combination with ICT, is not only a requirement of the new age, but an opportunity to find alternative modes of operating in the dynamically changing media market. A certain significance is carried by economic conditions, which require the traditional communication media sector, the printed press in particular, to seek new modes of conducting their operations. Based on federal data regarding employment in the USA, in 2000-2008, the media sector dwindled by more than 200,000 jobs. The reductions mostly affected daily newspapers and magazines ${ }^{3}$. Among the laid off journalists, the largest group has for many years consisted of investigative reporters whose work is time-consuming, expensive, and precarious, yet does not guarantee a return on the investment. The new circumstances have encouraged contemporary muckrakers to seek other forms of economic existence in the profession where financing is based on crowdfunding, donations, grants, or acquiring funds for their operations through subscriptions, and including paid ads and announcements. Non-profit and for-profit operations have become methods of conducting online journalistic investigations, a fact which has been proven by the creation of muckraker websites within the last decade or so.

The goal of this article is to show that contemporary websites used by investigative reporters for organising investigations and propagating their outcomes are just as successful a means as the traditional channels of mass communication. Their usage not only consolidates the tried and tested techniques of discovering the truth hidden from the public, but develops them creatively tailoring them to the new conditions and challenges. To achieve that goal, I compare the experiences of

MO 2007, pp. 95-96; D. Anderson, P. Benjaminson, "Investigative Reporting”, Indiana University Press, Bloomington 1976, p. 84. It is noteworthy that the application of computers in journalism had been practised before. In 1952, CBS commissioned experts to use them to predict the results of the presidential election, and in 1967 Philip Meyer of The Detroit Free Press analysed in a similar manner the results of a population study regarding the riots which erupted in the summer in the city. Similar investigations (with the use of computers) were also conducted in the USA in the 1980s. Elliot Jaspin of The Providence Journal Bulletin analysed databases for the purposes of investigations regarding reckless school bus drivers, and a political scandal related to mortgage loans, while for a series of articles on the significance of racial differences when approving mortgage loans The Atlanta Journal-Constitution received the Pulitzer Prize in 1989 (vide: B. Houston, "Fifty Years of Journalism and Data: A Brief History", 12.11.2015, http://gijn.org/2015/11/12/fiftyyears-of-journalism-and-data-a-brief-history/ [accessed on: 10.03.2016]).

${ }^{3}$ C. Lewis, "A Social-Network Solution. How investigative reporting got back on its feet", Columbia Journalism Review 2009, March. To find out more on the subject of lay-offs in the media, including among investigative reporters and the problems with financing investigations: W. Adamczyk, "Dziennikarstwo śledcze w formule non-profit: ryzykowny eksperyment czy naturalna alternatywa?”, Przegląd Politologiczny 2014, Issue 2, p. 94. 
American and European muckrakers in conducting investigative activities through websites. The comparison indicates analogies and differences in the application of modern means of communication for: (1) seeking information regarding the investigations being conducted, (2) communication among the members of the investigative team, (3) presenting investigation outcomes, (4) acquiring funds for conducting the investigations (crowdfunding), and new information and informers (crowdsourcing), (5) introducing new forms of employment, and (6) implementing innovative forms of activity. For comparative purposes, I used the examples of such initiatives from both continents, three from the USA and seven from Europe. The difference in the numbers of the studied cases was due to the fact that I intended to show the specificity of European muckraker websites, which have creatively developed their mode of operation based on the American experience. The comparative study method used to that end seemed the most useful in order to illustrate the analogies and differences in the area. I excluded from the study websites of investigative organisations, because, in their case, the publication of the results of reporter investigations constitutes only one of their many forms of activity.

Due to the economic crisis which struck the traditional media, and the resulting reduction in employment, a large group of investigative reporters decided to shift their professional activity to the internet. That was mainly caused by the search for new forms of financing their activity outside the media mainstream. To some extent, the exodus was a result of the policy implemented by large media corporations. As Samarth Vaidya, an Indian economist, has noted, the large, older media companies, established in the market, have a tendency for engaging in investigations only if they expect a sufficiently high profit from revealing various scandals, and the expected gains justify increased expenditure on that type of activity ${ }^{4}$. Some of the emerging initiatives have, for obvious reasons, abandoned for-profit activity, and decided to operate pro bono publico without receiving income. It is noteworthy that the non-profit formula was used much earlier for establishing several other important bodies of investigative journalism. Those included, e.g.: The Center for Investigative Reporting (1977), Frontline (1983), and The Center for Public Integrity (1989). Some more recent projects of that nature worth mentioning, which used the internet for conducting journalistic investigations were: Voice of San Diego (2005), Spot.US (2008), and The Huffington Post Investigative Fund (2009)5.

\footnotetext{
${ }^{4}$ S.S. Coronel, "Opera, game theory and investigative journalism”, 29.03.2012, https://watchdogwatcher.com/category/business-models-for-watchdog-reporting/ [accessed on: 18.08.2013]; "Investigative Journalism in Europe", D. van Eijk (ed.), VVOJ, Amsterdam 2005.

${ }^{5}$ W. Adamczyk, "Od indywidualizmu do zespołowości: I-Teamy jako element ewolucji w sposobie prowadzenia dochodzeń przez reporterów śledczych”, Przeglą Politologiczny 2016, Issue 1, p. 151.
} 
Apart from economic considerations, the changing modes of operation of those new bodies which have traditionally been the focus of interest of muckrakers are of major significance in propagating the new form of operation of investigative reporters online. A new development in recent years has been the international cooperation between them. According to David E. Kaplan:

"The global numbers of international and regional organisations associating investigative journalists have been growing. Never before have we seen such wide cooperation between journalists in issues regarding international crime, including economic fraud, the destruction of the natural environment, problems in terms of security, healthcare, etc." ${ }^{\prime \prime}$. The indicated cooperation between investigative reporters constitutes a natural response to the changing challenges of today, which are mainly a result of the process of the globalisation of supranational forms of business activity and crime ${ }^{7}$. The arguments made by Lucia Naldi and Robert G. Picard are also valid. According to them the main reasons why reporters engage in a new form of activity has been, apart from the employment reductions in existing media companies, the dissatisfaction with the current level of journalism and the demise of printed newspapers ${ }^{8}$. It is noteworthy that the economic conditions and employment insecurity are inextricably linked to the level of professionalism and the care for journalists' professional ethics.

For the purposes of this analysis of the activities of muckraker websites, I studied a total of ten such projects. When selecting them, I used several criteria through which one can indicate the characteristic features of that type of project and conduct a comparison. The mode of financing was one of the key indicators. In that respect, the existing forms of acquiring funding for investigative operations (conducted online) indicate the currently available opportunities and the various degrees of risk associated with fulfilling a specific economic model. The second criterion, which directly resulted from the first one, was the size of annual financial resources acquired for the activities. That indicator enabled me to draw cautious conclusions as to the effectiveness of the studied forms of economic support of the discussed projects operating online. The third were the forms of conducting journalistic investigations. In that respect, the scope of various inter-

\footnotetext{
${ }^{6}$ B. Biel, "Reporterzy śledczy to dziennikarskie służby specjalne”, 23.02.2013, http://www.press. $\mathrm{pl} /$ tresc/30648,reporterzy-sledczy-to-dziennikarskie-sluzby-specjalne- [accessed on: 01.03.2013]. One example of such an investigation of an international nature was the initiative entitled "Migrants' Files" (vide: W. Adamczyk, "Migrants' Files jako przykład międzynarodowego śledztwa dziennikarskiego: studium przypadku”, in: „Polityczne i społeczne aspekty wielokulturowości. Migracje i mniejszości”, A. Adamczyk, A. Sakson, C. Trosiak (eds.), Wydawnictwo Naukowe Wydziału Nauk Politycznych i Dziennikarstwa Uniwersytetu Adama Mickiewicza, Poznan 2016).

7 A. Léchenet, "Dziennikarstwo danych: ponad granicami państw”, 04.03.2015, http://pl.ejo-online.eu/nowe-media/dziennikarstwo-danych-ponad-granicami-panstw [accessed on: 10.03.2015].

${ }^{8}$ L. Naldi, R.G. Picard, "Let's Start an Online News Site: Opportunities, Resources, Strategy, and Formational Myopia in Startups", Journal of Media Business Studies 2012, Issue 4, p. 70.
} 
net tools proved only supplementary to the classical techniques of investigative reporter work which have been known for a long time now. Then again, some applications for browsing the internet revealed previously unknown capabilities available for contemporary muckrakers. The fourth discriminant considered in the study was the mode of employment, and the qualifications of the investigative teams. The related differences between the assumed patterns perfectly indicated new tendencies in the analysed area. That was supplemented by the fifth criterion the awards achieved, which constitutes a confirmation of the quality and professionalism of the teams carrying out the investigative projects.

The discussed internet projects were created in 2007-2015, though in recent years there has been a visible spike in the formation of such initiatives. For the purposes of the study, I analysed the following muckraker websites:

1) in the USA:

- ProPublica

- Spot.US

- The Huffington Post Investigative Fund

2) in Europe:

- Mediapart (France)

- Project Italy (Italy)

- Migrants' Files (supranational project)

- Bellingcat (United Kingdom)

- Correct!v (Germany)

- YanukovychLeaks (Ukraine)

- Kulisy24 (Poland).

When selecting specific projects in Europe, I considered those which were created in the countries with long-lasting investigative journalism traditions (France, the UK, and Germany), former Eastern Bloc states (Poland and Ukraine), and one project with an international reach. Almost at the same time, on both continents, two projects were created which have remained the major models of functioning in the new conditions to be emulated. One of the oldest still functioning projects of that type, which is considered a role model for all other projects, is ProPublica. It was established in late-2007 by Paul E. Steiger (first online publications were posted in 2008), and its investigations are based on the work of the I-Team (in total, the project employs forty-seven people). In 2010, ProPublica received the Pulitzer Prize for Investigative Reporting, the first ever organisation publishing on the internet to do $\mathrm{so}^{9}$. In its materials, it raises both social and economic issues, and natural protection matters ${ }^{10}$.

\footnotetext{
${ }^{9}$ N. Fioretti, "Nowe dziennikarstwo? Śledcze i cyfrowe", 07.08.2010, http://pl.ejo-online.eu/ nowe-media/nowe-dziennikarstwo-sledcze-i-cyfrowe [accessed on: 17.08.2014].

${ }^{10}$ A. Hansen, R. Cox, "The Routledge Handbook of Environment and Communication", Routledge, New York 2015, p. 152.
} 
In 2007, the internet also became the new location for the activities of Edwy Plenel, a French investigative journalist. The information and muckraker website called Mediapart, which he established, employs forty-five people including thirty-one reporters, and has produced several widely discussed publications ${ }^{11}$. One of the first was a series of articles in 2010 in which the Mediapart I-Team revealed the unclear financial relationships between Nicolas Sarkozy, former president of France, and Liliane Bettencourt, the heir to the L'Oreal empire. They established that Bettencourt supposedly handed the president envelopes filled with cash ${ }^{12}$. Two years later Mediapart uncovered the activities of Jerome Cahuzac, minister for the budget, who gathered 600,000 euros in secret Swiss bank accounts ${ }^{13}$.

In October 2008 in the USA, David Cohn started a website called Spot.US. Operating based on so-called community-funded journalism (using a website for acquiring ideas for new investigations and financial support), for the first two years it was supported through a grant from The Knight Foundation (covering the period from 3 Oct 2008 to 5 Jan 2011) ${ }^{14}$. The reporters conducting investigations operated within the San Francisco Bay area. In November 2011, the website was taken over by Public Insight Network, a part of American Public Media. The project was terminated in February $2015^{15}$.

On 4 April 2009, Arianna Huffington, co-founder of The Huffington Post, one of the most popular information websites among internet users, announced the start of The Huffington Post Investigative Fund managed by Nick Penniman.

${ }^{11}$ A. Wagemans, "Beyond Jounalism - Charging for online journalism is not such a ridiculous idea after all. A case study of the French online newspaper Mediapart", University of Amsterdam, Amsterdam 2015, pp. 4-5.

${ }^{12}$ A. Sage, "Afera z przyjmowaniem środków na kampanię pogrąża Sarkozy’ego", 02.09.2011, http://www.polskatimes.pl/artykul/445862,afera-z-przyjmowaniem-srodkow-na-kampanie-pograza-sarkozyego,id,t.html [accessed on: 09.11.2015].

${ }^{13}$ C. Dubouloz, "Shoe Leather And Paywalls: A New Website Shakes French Politics, And Turns A Profit", 03.04.2013, https://www.worldcrunch.com/culture-society/shoe-leather-andpaywalls-a-news-website-shakes-french-politics-and-turns-a-profit [accessed on: 07.01.2016]; M. Kowalczyk, "Coś nowego", Press 2013, No. 6, pp. 52-54; P. Gumbel, "Plus ça change...", Nieman Reports 2014, Summer.

${ }^{14}$ T. Aitamurto, "The Impact of Crowdfunding on Journalism: Case study of Spot.US, a platform for Community-funded...”, Journalism Practice 2011, 5:4, pp. 429-445; "Spot.US", https:// www.knightfoundation.org/grants/20072587/ [accessed on: 03.02.2016]; R.J. Rouan, "The NonProfit Model of Investigative Reporting: Can it Save Public Service Journalism?", https://www. scripps.ohiou.edu/media/podcasts/j416/papers/rouan.pdf [accessed on: 22.05.2012]; S. Kershaw, "A Different Way to Pay for the News You Want", The New York Times 2008, 23.08, http://www. nytimes.com/2008/08/24/weekinreview/24kershaw.html?_r=1 [accessed on: 22.05.2012].

${ }^{15}$ A. Ha, "America Public Media Acquires Journalism Crowdfunding Service”, 30.11.2011, http://www.adweek.com/news/technology/american-public-media-acquires-journalism-crowdfunding-service-136778 [accessed on: 22.05 2012]; N. Usher, "Spot.us: A Case-Study of A New Business Model for News and its Implications for Journalists", Cinergie 2014, Issue 5, http://www. cinergie.it/?p=4088 [accessed on: 06.10.2015]. 
In line with the report once, run anywhere principle, the investigative material was posted on the website and made available free of charge to media outlets interested in using it. The new project became legally and editorially independent of HuffPost. In the face of the economic crisis in the traditional media and lay-offs of investigative journalists, the project was supposed to utilise the potential of those reporters, and to continue the traditions of investigative journalism in the USA based on new technologies. Experienced journalists were supposed to be supported by freelancers. The Huffington Post spent 1.75 million dollars on the project. Another significant donor was The Atlantic Philanthropies. In October 2010, The Huffington Post Investigative Fund and The Center for Public Integrity merged, thus forming one of the largest teams of investigative journalists in the country with over 50 reporters. The John S. and James L. Knight Foundation donated 250.000 dollars the new project (earlier it had supported CPI with 1.7 million dollars for the development of innovative digital platforms). The Huffington Post assigned 2 million dollars for the financing of the project in the form of a grant, and undertook to post three content pieces on its website each day and previews of articles in a specially-created investigative section ${ }^{16}$.

The idea to create Project Italy was born in October 2011 in Kiev during the $7^{\text {th }}$ Global Investigative Journalism Conference. Eight Italian journalists, capitalising on the American models, decided to integrate their individual efforts to combat organised crime. Towards that end, in January 2013, the first Italian body under the name of Investigative Reporting Project Italy was established. Its main source of financing, apart from donations and grants, was supposed to be income from the sales of products and publishing services, and crowdfunding. In the late-2013, on their website they started IRPILEAKS, which is a platform for sending in anonymous leaks, and particularly protecting the identity of the whistleblowers ${ }^{17}$.

In August 2013, French journalist Nicolas Kayser-Bril, moved by the events in Europe associated with the massive inflow of economic immigrants and refugees

\footnotetext{
${ }^{16}$ K. Carmichael, "Investigations with Impact", American Journalism Review 2010, March; A. Huffington, "Announcing the Launch of the Huffington Post Investigative Fund", 04.04.2009, "The Huffington Post", http://www.huffingtonpost.com [accessed on: 25.08.2013]; L. Jr. Downie, M. Schudson, "The Reconstruction of American Journalism", Columbia Journalism Review 2009, 20.10; D. Westphal, "Foundations Invest in Watchodg Reporting as Group Considers National Investigative Network", 27.06.2009, https:/www.poynter.org/2009/foundations-invest-in-watchdogreporting-as-group-considers-national-investigative-network/96559/ [accessed on: 26.08.2013].

17 “IRPI - About Us", https://irpi.eu/en/about-us/ [accessed on: 19.01.2015]; "IRPILEAKS, first Italian platform for anonymous leaking to investigative journalism", 07.10.2013, https://www. hermescenter.org/irpileaks-italian-anonymous-leaking-investigative-journalism, [accessed on: 19.01.2015]; H. Spyksma, "Mundus alumna forms investigative reporting centre", 05.08.2013, http://mundusjournalism.com/our-people/alumni/alumni-profiles/nyhed/artikel/mundus-alumnaforms-investigative-reporting-centre [accessed on: 19.01.2015]; "Giornalismo investigativo: Irpi, un progetto italiano con respiro globale", 16.01.2013, http://www.lsdi.it/2013/giornalismo-investigativo-un-progetto-italiano-con-respiro-globale [accessed on: 19.01.2015].
} 
from Africa and the Middle East, decided to invite investigative journalists, specialists in data journalism, and the editorial boards of media outlets from various European countries to cooperate in a project entitled "Migrants' Files". The main challenge for the collaborators was to collect reliable data from various independent sources, and utilise the existing calculations regarding the deaths of refugees coming to Europe illegally. By using the OSINT method, and modern online tools, they were able to assess the number of confirmed fatal accidents within the period of 1 January 2000 to November 2015 (31,478 were recorded). Thanks to the analysis of the routes immigrants and refugees used to reach Europe, it was also possible to locate the most dangerous locations, and assess the expenses of EU Member States incurred in relation to the exodus. On the website, they also posted an approximation of the profits of organised groups which conducted illegal transport of people via the Mediterranean or over land. On 24 June 2016, upon collecting, updating, and organising the new data, the project officially concluded ${ }^{18}$.

In 2014, three more muckraker website were established in Europe. In the United Kingdom, thanks to the financial backing of 96,000 dollars acquired through the Kickstarter website, Bellingcat was established. It was created by Elliot Higgins. In his investigations, he used OSINT and geolocation methods. Using the latter he was able to, i.a. reveal the complicity of Russian troops in the shooting down over Ukraine of a Boeing 777, flight MH17 which departed from Amsterdam and was flying to Kuala Lumpur. Through geolocation, Higgins was also able to specify the location where James Foley, an American journalist, was held in an area seized by the so-called Islamic State (IS) in the north-central part of Syria. Based on his investigations, acclaimed world media outlets (CNN, The Guardian, The Independent, The New Yorker, The Huffington Post) offered the creator of Bellingcat the position of expert on Syria ${ }^{19}$.

${ }^{18}$ W. Adamczyk, "Migrants' Files jako przykład...”; T. Last, T. Spijkerboer, “Tracking Deaths in the Mediterranean", in: "Fatal Journeys. Tracking Lives Lost During Migration", T. Brian and F. Laczko (eds.), International Organization for Migration, Geneva 2014; EUobserver, "The Migrants' Files: surveying migrants' deaths at Europe's door", EUobserver 2014, 31.03; S. Gruhnwald, A. Kohli, "Making of 'The Migrants' Files'. Daten einer Tragödie", 31.03.2014, http://www. nzz.ch/daten-einer-tragoedie-1.18272916 [accessed on: 19.01.2015]; N. Kayser-Bril, "The Migrants Files: A Quantitative Approach to Migration Policy", https://www.law.ox.ac.uk/research-subjectgroups/centre-criminology/centreborder-criminologies/blog/2014/05/migrants-files [accessed on: 19.01.2015].

${ }^{19}$ C. Massie, "Watch out for Bellingcat", Columbia Journalism Review, 12.01.2015, http://www. cjr.org/business_of_news/bellingcat_brown_moses.php [accessed on: 10.02.2016]; B. Schatz, “These Digital Sleuths Are Sticking It to ISIS and the Kremlin”, Mother Jones 2016, January/February; C. Albeanu, "Bellingcat: open source intelligence 'vastly under-tapped' by media", 29.05.2015, http://www.journalism.co.uk [accessed on: 11.02.2016], J. Weiss, "Bellingat site wants to teach people how to verify online information", International Journalists' Network, 09.09.2014, http:// ijnet.org [accessed on: 11.02.2016], V. Craw, "Bellingcat citizen journalist Elliot Higgins is holding global governments to account", 29.01.2015, http://www.news.com.au [accessed on: 11.02.2016]. 
Another interesting project is Correct!v, the first muckraker website in German-speaking countries. It was established on 1 July 2014 by David Schraven and Christian Humborg with financial backing from The Borst Foundation (a grant of 1 million euros for 3 years). The editorial team consists of 20 employees (reporters and editors) and over 50 volunteers. The German investigative reporters modelled their work on the American website ProPublica. The issues raised in the investigations are diverse: from free trade, through money laundering and organised crime, to the neo-Nazi underground and immigration issues ${ }^{20}$.

A different type of online investigative project is the YanukovychLeaks.org website. It was established in February 2014 by a group of fifteen Ukrainian investigative journalists from eleven editorial boards. They tracked down and saved from being destroyed thousands of documents left by Viktor Yanukovych, former Ukrainian president, which proved the instances of bribery and abuse of power he had committed. Its uniqueness consisted in the fact that it was devoted to only uncovering the illegal actions of the former president. The information regarding his dealings was acquired from thousands of documents sunk in a lake near the Mezhyhirya presidential mansion by his collaborators prior to his escape to Russia. Upon being recovered from the lake, dried, and scanned, they were posted on the internet. On the first day after posting the thousands of documents saved from destruction, YanukovychLeaks.org recorded 2 million entries ${ }^{21}$.

In Poland, the only website which states its investigative nature is the Kulisy24 investigative website, established on 18 June 2015. It was based on investigative reporters who had previously worked for the Wprost weekly and left it together with Sylwester Latkowski, the editor-in-chief. The new I-Team consisted of: Agnieszka

${ }^{20}$ R. Stern, “Investigative Journalism Goes Online in Germany”, 28.11.2014, http://en.ejo.ch/ specialist-journalism/investigative-reporting-goes-online-germany [accessed on: 07.05.2015]; C. O'Donovan, "Germany is getting a data-centric nonprofit newsroom and hoping to build new models for news", 17.07.2014, http://www.niemanlab.org/2014/07/germany-is-getting-a-data-centric-nonprofit-newsroom-and-hoping-to-build-new-models-for-news/ [accessed on: 07.05.2015]; “About Correct!v", https://correctiv.org/en/correctiv/ [accessed on: 07.05.2015].

${ }^{21}$ D.E. Kaplan, "Yanukovychleaks Update: 'The Project Is Becoming Bigger”, 27.02.2014, https://gijn.org/2014/02/27/yanukovychleaks-update-the-project-is-becoming-bigger/ [accessed on: 11.05.2014]; S. Ricchiardi, "Reassembling Ukraine's Secrets, Piece by Shredded Piece", American Journalism Review 2014, March; D. Sullivan, "YanukovychLeaks: How Ukraine Journalists Are Making History", 25.02.2014, http://gijn.org/2014/02/25/yanukovychleaks-orghow-ukraine-journalists-are-making-history [accessed on: 20.08.2014]; N. Porzucki, K. Chernichkin, "How a team of Ukrainian journalists rescued documents from Yanukovych's house", 27.02.2014, http://www.pri.org/stories/2014-02-27/how-team-ukrainian-journalists-rescued-documents-yanukovych-s-house [accessed on: 11.05.2014]; R. Palmer, "Chasing Paper with YanukovychLeaks. How a team of Ukrainian journalists raced to recover documents that detailed excesses by the country's president", 15.02.2014, http://niemanreports.org/articles/chasing-paperwith-yanukovychleaks [accessed on: 20.08.2014]; C. Schneider, "Enthüllungsjournalismus in der Ukraine", 04.07.2014, http://netzwerkrecherche.org/wordpress/blog14/enthuellungsjournalismus-inder-ukraine/ [accessed on: 20.08.2014]. 
Burzyńska, Michał Majewski, Izabela Smolińska, Paulina Socha-Jakubowska, Olga Wasilewska and Barbara Lang, and Cezary Łazarewicz as a collaborator. The website operates based on a non-profit formula, and in the initial period of its activity it received financial support from Fundacja Wolne Słowo, the chairman of which is Latkowski, and his Artnet company. In early-2016, Socha-Jakubowska and Burzyńska resigned, and Wasilewska and Smolińska suspended their cooperation with the website ${ }^{22}$.

In comparative studies of muckraker websites, one of the most important criteria for differentiating them is their mode of financing (Table 1). Such projects are usually based on innovative forms of acquiring funds, which is characteristic of editorial boards operating online. Apart from crowdfunding, other common forms of support include donations from foundations and restricted grants. In some cases, services provided for external entities constitute an additional source of income. The need to acquire larger sums which enable, on the one hand, intensifying the investigations, and, on the other, increasing the wages of the reporters, has forced some to include ads on their websites (ProPublica has been doing that since 2011). Mediapart is a special case in the discussed group of online projects as it operates according to the motto of Edwy Plenel: "we can only be bought by our readers." It initially received 3 million euros from its founding members, the Friends of Mediapart association, and government subsidies. Its main source of financing is a subscription. What is interesting, as early as 2010, the website achieved financial equilibrium, and has been turning a profit since the following year. In September 2014, the number of its subscribers reached 100,000, which became the guarantee of Mediapart's financial independence ${ }^{23}$.

Table 1. Investigative journalism websites (mode of financing)

\begin{tabular}{|c|c|}
\hline Website & Mode of financing \\
\hline ProPublica & donations, ads (since 2011) \\
\hline Spot.US & crowdfunding \\
\hline HP Investigative Fund & donations from donors \\
\hline Mediapart & subscription \\
\hline
\end{tabular}

${ }^{22}$ Ł. Brzezicki, "Kulisy24 trafiły w lukę po dziennikarstwie śledczym. O wsparcie od czytelników łatwiej niż o reklamodawców (opinie)", 28.07.2015, http://www.wirtualnemedia.pl/artykul/ kulisy24-trafily-w-luke-po-dziennikarstwie-sledczym-o-wsparcie-od-czytelnikow-latwiej-niz-o-reklamodawcow-opinie [accessed on: 16.08.2015]; E. Rutkowska, "Wystartował serwis Sylwestra Latkowskiego - Kulisy24”, 19.06.2015, http://www.press.pl [accessed on: 21.06.2015]; MAK, JM, "Latkowski zapewnia, że to jeszcze nie koniec serwisu Kulisy24.com", 22.02.2016, http:// www.press.pl/tresc/42877,latkowski-zapewnia_-ze-to-jeszcze-nie-koniec-serwisu-kulisy24_com [accessed on: 25.06.2016].

${ }^{23}$ A. Wagemans, op. cit., p. 4; M. Kowalczyk, op. cit. 


\begin{tabular}{|c|c|}
\hline Migrants' Files & grants \\
\hline Project Italy & donations, grants, services \\
\hline Bellingcat & crowdfunding \\
\hline Correct!v & donations from donors \\
\hline YanukovychLeaks & no information \\
\hline Kulisy24 & $\begin{array}{c}\text { support from Fundacja Wolne Słowo, } \\
\text { individual donations from readers }\end{array}$ \\
\hline
\end{tabular}

Source: own study.

Another criterion illustrating the economic side of online projects with investigative journalists is the size of the annual budget (Table 2). ProPublica, which operates based on donations and income from ads, is in the best situation, and in $2015 \mathrm{had}$ at its disposal almost 13 million dollars. In terms of financial resources, Mediapart is also in a good situation. In March 2016, the number of its subscribers exceeded 118,000, which means that the website will considerably increase its income compared to 2012 when it had at its disposal 6 million euros. Some projects like Bellingcat or Migrants' Files were fulfilled for relatively small amounts of money, which came from grants and donations. Some problems with planning long-term operations are associated with crowdfunding-based financing. Though the method offers huge possibilities, the example of Spot.US shows that it cannot be considered a stable source of income.

Table 2. Investigative journalism websites (annual budget)

\begin{tabular}{|c|c|}
\hline Website & Annual budget \\
\hline ProPublica & approx. 13 million dollars (2015) \\
\hline Spot.US & 340,000 dollars (2008) \\
\hline HP Investigative Fund & 2 million dollars \\
\hline Mediapart & 6 million dollars (2012) \\
\hline Migrants` Files & n,000 euros \\
\hline Project Italy & no, information \\
\hline Bellingcat & approx. 2 million euros (2015) \\
\hline Correct!v & no information \\
\hline YanukovychLeaks & no information \\
\hline Kulisy24 &
\end{tabular}

Source: own study.

In terms of the analogies and differences, the manner of conducting investigations by the members of muckraker websites is important. Though their operations are conducted online, a significant group of editorial teams use classical 
investigative methods and techniques, which bear excellent results. That is mainly due to the fact that new online projects gathered investigative reporters with many years of experience, who have been shaped by professional procedures applicable in traditional media. Journalists operating online also utilise in their investigations innovative tools for acquiring and verifying information (crowdsourcing, geolocation, OSINT, data journalism), which enable them to overcome the technological limitations they had faced in the past. That also offers them an opportunity to cooperate with each other in their investigations, something that was non-existent between editorial teams not only located in different countries, but even, with a few exceptions, media outlets operating within the same domestic market. Contemporary online muckrakers often use social media, where they seek out content significant for their investigations. Their results can be found not only on the websites, but also in traditional media to whom they are released for a fee or free of charge (Table 3).

Table 3. Investigative journalism websites (mode of operation)

\begin{tabular}{|l|l|}
\hline Website & Mode of operation \\
\hline ProPublica & classical investigative journalism \\
\hline Spot.US & crowdsourcing, Creative Commons licence \\
\hline HP Investigative Fund & classical investigative journalism + online tools \\
\hline Mediapart & classical investigative journalism \\
\hline Migrants' Files & data journalism, OSINT, geolocation \\
\hline Project Italy & classical investigative journalism \\
\hline Bellingcat & geolocation, open source, social media \\
\hline Correct!ve & $\begin{array}{l}\text { classical investigative journalism, data journalism, } \\
\text { state-of-the-art technology }\end{array}$ \\
\hline YanukovychLeaks & classical investigative journalism \\
\hline Kulisy24 & classical investigative journalism \\
\hline
\end{tabular}

Source: own study.

Considerable differences among the discussed muckraker websites can be found in the manner of conducting their HR policies. Major projects, which possess stable financial backing, have based their operations mainly on employees (ProPublica, Mediapart, HPInvestigative Fund, Correct!v) who are supported by freelancers. The others constitute a core of websites which are financed through grants, crowdfunding, and time-limited donations. That seems to be an attempt at minimising costs so that the resulting savings could be assigned to investigation-related expenditures. However, that creates a sense of uncertainty among the members of the editorial teams, who find it difficult to plan their professional ca- 
reers in such circumstances (Table 4). Data journalism, visualisation, and geolocation specialists have introduced a new standard to the operations of muckraker websites, as their skills have opened previously completely unknown possibilities to the reporters who form the I-Teams.

Table 4. Investigative journalism websites (staff, mode of cooperation)

\begin{tabular}{|l|l|}
\hline Website & Staff, mode of cooperation \\
\hline ProPublica & $\begin{array}{l}\text { experienced editors, investigative reporters; } \\
\text { employees + freelancers }\end{array}$ \\
\hline Spot.US & David Cohn; freelancers \\
\hline HP Investigative Fund & $\begin{array}{l}\text { experienced editors, investigative reporters; } \\
\text { employees + freelancers }\end{array}$ \\
\hline Mediapart & experienced editors, investigative reporters; employees \\
\hline Migrants' Files & $\begin{array}{l}\text { investigative reporters, data journalism, OSINT, } \\
\text { visualisation specialists; freelancers }\end{array}$ \\
\hline Project Italy & $\begin{array}{l}\text { experienced journalists and investigative reporters; } \\
\text { only member of IRPJ }\end{array}$ \\
\hline Bellingcat & Eliot Higgins; collaborators \\
\hline Correct!ve & $\begin{array}{l}\text { experienced editors, investigative reporters; } \\
\text { employees + freelancers }\end{array}$ \\
\hline YanukovychLeaks & experienced investigative reporters; volunteers \\
\hline Kulisy24 & experienced editors, investigative reporters; employees \\
\hline
\end{tabular}

Source: own study.

The final element for describing the operations of investigative websites are awards and distinctions for completed investigations. Some of the discussed projects have already received several dozen such distinctions (ProPublica). Apart from two instances (Spot.US and Kulisy24), each of the websites has received prestigious awards in investigative journalism. I-Teams operating online successfully compete in that respect with representatives of the traditional media, who until recently were the only recipients of such distinctions. The fact that the juries awarding the prizes have recognised the quality of the work of online muckrakers offers also an argument for further development of the formula, which for some time had not been treated seriously (Table 5). It is also interesting that prestigious distinctions were offered to single-focus projects (Migrants' Files and YanukovychLeaks), the durability of which (due to their specific character) is limited. 
Table 5. Investigative journalism websites (awards)

\begin{tabular}{|c|c|}
\hline Website & Awards \\
\hline ProPublica & Pulitzer Prize, Data Journalism Award, IRE, ASNE \\
\hline Spot.US & no information \\
\hline HP Investigative Fund & IRE, Online News Association, SPJ \\
\hline Mediapart & Grand prix des medias \\
\hline Migrants' Files & Data Journalism Award, European Press Prize \\
\hline Project Italy & Google's Digital News Initiative \\
\hline Bellingcat & Hanns-Joachim-Friedrichs-Award \\
\hline Correct!ve & Grimme Online Award, Franco-German Journalism \\
& Award \\
\hline YanukovychLeaks & Reporters Foundation Award, Global Shining Light \\
& Award (GIJN) \\
\hline Kulisy24 & no information \\
\hline
\end{tabular}

Source: own study.

\section{Conclusion}

Muckraker websites have permanently entered the landscape of the contemporary media. In the times of economic crisis, plummeting interest in traditional media, and their dwindling profitability, online investigative journalism can offer a way out. That is confirmed in the growing common global trend present outside of mainstream media outlets employing investigative reporters ${ }^{24}$. New methods of acquiring funding and conducting investigations are the reasons why it has become necessary to redefine, to some extent, the term muckraker, a person who, mainly due to economic reasons and an ever increasing risk of costly law suits detrimental for the image of media outlets, has been forced to seek on her/his own new sources of financing for her/his work ${ }^{25}$. However, considering the increasing expenditure on online advertising, and the generosity of donors, one can assume with considerable certainty that there will emerge more and more such projects, while the procedures used in editorial work will, mainly through technological innovation, be creatively developed.

${ }^{24}$ C.S. Stepp, "Is investigative Reporting Here to Stay?", American Journalism Review 2006, December/January.

${ }^{25}$ G.R. Baggi, "Nonprofit Investigative Journalism in Europe: Motives, Organisations and Practices”, Hamburg 2011, pp. 8-9; "Investigative Journalism In Europe”, pp. 12-25. 


\section{Bibliography}

"About Correct!v", https://correctiv.org/en/correctiv/ [accessed on: 07.05.2015].

Adamczyk W., "Amerykańskie archetypy dziennikarstwa śledczego", Wydawnictwo Naukowe Wydziału Nauk Politycznych i Dziennikarstwa Uniwersytetu Adama Mickiewicza, Poznan 2008.

Adamczyk W., "Dziennikarstwo śledcze w formule non-profit: ryzykowny eksperyment czy naturalna alternatywa?”, Przeglad Politologiczny 2014, Issue 2, pp. 93-110.

Adamczyk W., “Migrants' Files jako przykład międzynarodowego śledztwa dziennikarskiego: studium przypadku”, in: „Polityczne i społeczne aspekty wielokulturowości. Migracje i mniejszości”, A. Adamczyk, A. Sakson, C. Trosiak (eds.), Wydawnictwo Naukowe Wydziału Nauk Politycznych i Dziennikarstwa Uniwersytetu Adama Mickiewicza, Poznan 2016.

Adamczyk W., "Od indywidualizmu do zespołowości: I-Teamy jako element ewolucji w sposobie prowadzenia dochodzeń przez reporterów śledczych”, Przegląd Politologiczny 2016, Issue 1, pp. 143-163.

Aitamurto T., "The Impact of Crowdfunding on Journalism: Case study of Spot.US, a platform for Community-funded...", Journalism Practice 2011, 5:4, pp. 429-445.

Albeanu C., "Bellingcat: open source intelligence 'vastly under-tapped' by media", 29.05.2015, http://www.journalism.co.uk [accessed on: 11.02.2016].

Anderson D., Benjaminson P., "Investigative Reporting”, Indiana University Press, Bloomington 1976.

Aucoin J.L., "Investigative Journalism", in: "American Journalism: History, Principles, Practices", W.D. Sloan, L.M. Parcell (eds.), McFarland, Jefferson, NC 2002.

Aucoin J.L., "The Evolution of American Investigative Journalism", University of Missouri Press, Columbia, MO 2007.

Baggi G.R., "Nonprofit Investigative Journalism in Europe: Motives, Organisations and Practices”, Hamburg 2011, pp. 8-9.

Biel B., "Reporterzy śledczy to dziennikarskie służby specjalne”, 23.02.2013, http://www. press.pl/tresc/30648,reporterzy-sledczy-to-dziennikarskie-sluzby-specjalne- [accessed on: 01.03.2013].

Brzezicki Ł., "Kulisy24 trafiły w lukę po dziennikarstwie śledczym. O wsparcie od czytelników łatwiej niż o reklamodawców (opinie)", 28.07.2015, http://www.wirtualnemedia.pl/artykul/ kulisy24-trafily-w-luke-po-dziennikarstwie-sledczym-o-wsparcie-od-czytelnikow-latwiej-niz-o-reklamodawcow-opinie [accessed on: 16.08.2015].

Carmichael K., "Investigations with Impact”, American Journalism Review 2010, March.

Coronel S.S., "Opera, game theory and investigative journalism”, 29.03.2012, https://watchdog-watcher.com/category/business-models-for-watchdog-reporting/ [accessed on: 18.08.2013].

Craw V., "Bellingcat citizen journalist Elliot Higgins is holding global governments to account", 29.01.2015, http://www.news.com.au [accessed on: 11.02.2016].

Downie L.Jr., Schudson M., “The Reconstruction of American Journalism”, Columbia Journalism Review 2009, 20.10.

Dubouloz C., "Shoe Leather And Paywalls: A New Website Shakes French Politics, And Turns A Profit", 03.04.2013, https://www.worldcrunch.com/culture-society/shoe-leather-and-paywalls-a-news-website-shakes-french-politics-and-turns-a-profit [accessed on: 07.01.2016].

EUobserver, “The Migrants' Files: surveying migrants' deaths at Europe's door", EUobserver $2014,31.03$. 
Fioretti N., "Nowe dziennikarstwo? Śledcze i cyfrowe", 07.08.2010, http://pl.ejo-online.eu/nowe-media/nowe-dziennikarstwo-sledcze-i-cyfrowe [accessed on: 17.08.2014].

“Giornalismo investigativo: Irpi, un progetto italiano con respiro globale", 16.01.2013, http://www. 1sdi.it/2013/giornalismo-investigativo-un-progetto-italiano-con-respiro-globale [accessed on: 19.01.2015].

Gruhnwald S., Kohli A., "Making of 'The Migrants' Files'. Daten einer Tragödie”, 31.03.2014, http://www.nzz.ch/daten-einer-tragoedie-1.18272916 [accessed on: 19.01.2015].

Gumbel P., "Plus ça change...", Nieman Reports 2014, Summer.

Ha A., "America Public Media Acquires Journalism Crowdfunding Service", 30.11.2011, http:// www.adweek.com/news/technology/american-public-media-acquires-journalism-crowdfunding-service-136778 [accessed on: 22.05 2012].

Hansen A., Cox R., "The Routledge Handbook of Environment and Communication”, Routledge, New York 2015.

Houston B., "Fifty Years of Journalism and Data: A Brief History", 12.11.2015, http:/gijn.org /2015/11/12/fifty-years-of-journalism-and-data-a-brief-history/ [accessed on: 10.03.2016].

Huffington A., "Announcing the Launch of the Huffington Post Investigative Fund", 04.04.2009, "The Huffington Post", http://www.huffingtonpost.com [accessed on: 25.08.2013].

“Investigative Journalism In Europe”, D. van Eijk (ed.), VVOJ, Amsterdam 2005.

"IRPI - About Us", https://irpi.eu/en/about-us/ [accessed on: 19.01.2015].

"IRPILEAKS, first Italian platform for anonymous leaking to investigative journalism", 07.10.2013, https:/www.hermescenter.org/irpileaks-italian-anonymous-leaking-investigative-journalism, [accessed on: 19.01.2015].

Kaplan D.E., "Yanukovychleaks Update: 'The Project Is Becoming Bigger’,, 27.02.2014, https:// gijn.org/2014/02/27/yanukovychleaks-update-the-project-is-becoming-bigger/ [accessed on: 11.05.2014].

Kayser-Bril N., “The Migrants Files: A Quantitative Approach to Migration Policy", https:// www.law.ox.ac.uk/research-subject-groups/centre-criminology/centreborder-criminologies/ blog/2014/05/migrants-files [accessed on: 19.01.2015].

Kershaw S., "A Different Way to Pay for the News You Want", The New York Times 2008, 23.08, http:// www.nytimes.com/2008/08/24/weekinreview/24kershaw.html?_r=1 [accessed on: 22.05.2012].

Kowalczyk M., “Coś nowego", Press 2013, Issue 6, pp. 52-54.

Last T., Spijkerboer T., "Tracking Deaths in the Mediterranean", in: "Fatal Journeys. Tracking Lives Lost During Migration", T. Brian and F. Laczko (eds.), International Organization for Migration, Geneva 2014.

Léchenet A., "Dziennikarstwo danych: ponad granicami państw", 04.03.2015, http://pl.ejo-online. eu/nowe-media/dziennikarstwo-danych-ponad-granicami-panstw [accessed on: 10.03.2015].

Lewis C., "A Social-Network Solution. How investigative reporting got back on its feet", Columbia Journalism Review 2009, March.

MAK, JM, "Latkowski zapewnia, że to jeszcze nie koniec serwisu Kulisy24.com", 22.02.2016, http://www.press.pl/tresc/42877,latkowski-zapewnia_-ze-to-jeszcze-nie-koniec-serwisu-kulisy24_com [accessed on: 25.06.2016].

Massie C., "Watch out for Bellingcat", Columbia Journalism Review, 12.01.2015, http://www.cjr. org/business_of_news/bellingcat_brown_moses.php [accessed on: 10.02.2016].

Naldi L., Picard R.G., "Let's Start an Online News Site: Opportunities, Resources, Strategy, and Formational Myopia in Startups", Journal of Media Business Studies 2012, Issue 4, p. 69-97. 
O'Donovan C., "Germany is getting a data-centric nonprofit newsroom and hoping to build new models for news", 17.07.2014, http:/www.niemanlab.org/2014/07/germany-is-getting-a-data-centric-nonprofit-newsroom-and-hoping-to-build-new-models-for-news/ [accessed on: 07.05.2015].

Palmer R., "Chasing Paper with YanukovychLeaks. How a team of Ukrainian journalists raced to recover documents that detailed excesses by the country's president”, 15.02.2014, http:// niemanreports.org/articles/chasing-paper-with-yanukovychleaks [accessed on: 20.08.2014].

Porzucki N., Chernichkin K., "How a team of Ukrainian journalists rescued documents from Yanukovych's house", 27.02.2014, http://www.pri.org/stories/2014-02-27/how-team-ukrainian-journalists-rescued-documents-yanukovych-s-house [accessed on: 11.05.2014].

Ricchiardi S., "Reassembling Ukraine's Secrets, Piece by Shredded Piece", American Journalism Review 2014, March.

Rivers W.L., Mathews C., "Etyka środków przekazu”, transl. by J. Zakrzewski, E. Krasnodębska, Ars Polonia, Warsaw 1995.

Rouan R.J., "The Non-Profit Model of Investigative Reporting: Can it Save Public Service Journalism?", https://www.scripps.ohiou.edu/media/podcasts/j416/papers/rouan.pdf [accessed on: 22.05.2012].

Rutkowska E., "Wystartował serwis Sylwestra Latkowskiego - Kulisy24", 19.06.2015, http:// www.press.pl [accessed on: 21.06.2015].

Sage A., "Afera z przyjmowaniem środków na kampanię pogrąża Sarkozy’ego”, 02.09.2011, http:// www.polskatimes.pl/artykul/445862, afera-z-przyjmowaniem-srodkow-na-kampanie-pograza-sarkozyego,id,t.html [accessed on: 9.11.2015].

Schatz B., "These Digital Sleuths Are Sticking It to ISIS and the Kremlin", Mother Jones 2016, January/February.

Schneider C., "Enthüllungsjournalismus in der Ukraine”, 04.07.2014, http://netzwerkrecherche. org/wordpress/blog14/enthuellungsjournalismus-in-der-ukraine/ [accessed on: 20.08.2014].

“Spot.US", https://www.knightfoundation.org/grants/20072587/ [accessed on: 03.02.2016].

Spyksma H., "Mundus alumna forms investigative reporting centre", 05.08.2013, http://mundusjournalism.com/our-people/alumni/alumni-profiles/nyhed/artikel/mundus-alumna-forms-investigative-reporting-centre [accessed on: 19.01.2015].

Stepp C.S., "Is investigative Reporting Here to Stay?", American Journalism Review 2006, December/January.

Stern R., "Investigative Journalism Goes Online in Germany", 28.11.2014, http://en.ejo.ch/specialist-journalism/investigative-reporting-goes-online-germany [accessed on: 07.05.2015].

Sullivan D., "YanukovychLeaks: How Ukraine Journalists Are Making History", 25.02.2014, http://gijn.org/2014/02/25/yanukovychleaks-org-how-ukraine-journalists-are-making-history [accessed on: 20.08.2014].

Usher N., "Spot.us: A Case-Study of A New Business Model for News and its Implications for Journalists", Cinergie 2014, Issue 5, pp. 139-145, http://www.cinergie.it/?p=4088 [accessed on: 06.10.2015].

Wagemans A., "Beyond Jounalism - Charging for online journalism is not such a ridiculous idea after all. A case study of the French online newspaper Mediapart", University of Amsterdam, Amsterdam 2015.

Weiss J., "Bellingat site wants to teach people how to verify online information", International Journalists' Network, 09.09.2014, http://ijnet.org [accessed on: 11.02.2016]. 
Westphal D., "Foundations Invest in Watchodg Reporting as Group Considers National Investigative Network", 27.06.2009, https://www.poynter.org/2009/foundations-invest-in-watchdog-reporting-as-group-considers-national-investigative-network/96559/ [accessed on: 26.08.2013].

Wojciech Adamczyk

\section{Muckraker websites (American and European examples)}

\section{(Summary)}

The goal of the article is to compare contemporary websites used by investigative reporters for organising their inquiries and propagating their outcomes. To achieve that goal, I compare the experiences of American and European muckrakers in conducting investigative activities through websites. I analysed 10 such projects in total, 3 from the USA and 7 from Europe. The discussed criteria include the modes of financing, the size of annual budgets, the modes of operation, and HR policies.

Keywords: investigative reporters, muckrakers, Internet. 